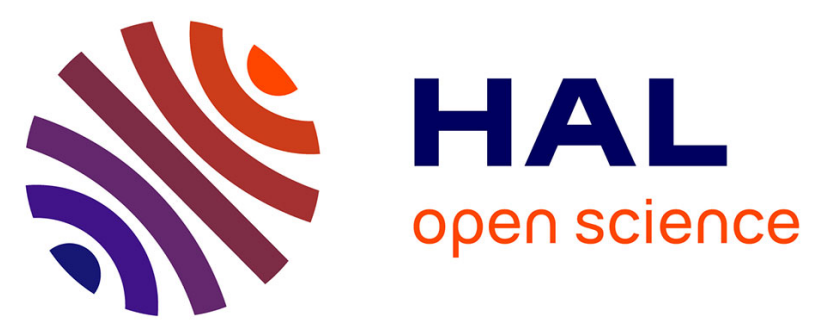

\title{
Combined XRF, XRD, SEM-EDS, and Raman Analyses on Serpentinized Harzburgite (Nickel Laterite Mine, New Caledonia): Implications for Exploration and Geometallurgy
}

Yassine El Mendili, Daniel Chateigner, Beate Orberger, Stéphanie Gascoin, Jean-François Bardeau, Sebastien Petit, Cedric Duee, Monique Le Guen, Henry Pilliere

\section{- To cite this version:}

Yassine El Mendili, Daniel Chateigner, Beate Orberger, Stéphanie Gascoin, Jean-François Bardeau, et al.. Combined XRF, XRD, SEM-EDS, and Raman Analyses on Serpentinized Harzburgite (Nickel Laterite Mine, New Caledonia): Implications for Exploration and Geometallurgy. ACS Earth and Space Chemistry, 2019, 3, pp.2237-2249. 10.1021/acsearthspacechem.9b00014 . hal-02380991

\author{
HAL Id: hal-02380991 \\ https://hal.science/hal-02380991
}

Submitted on 5 Dec 2019

HAL is a multi-disciplinary open access archive for the deposit and dissemination of scientific research documents, whether they are published or not. The documents may come from teaching and research institutions in France or abroad, or from public or private research centers.
L'archive ouverte pluridisciplinaire HAL, est destinée au dépôt et à la diffusion de documents scientifiques de niveau recherche, publiés ou non, émanant des établissements d'enseignement et de recherche français ou étrangers, des laboratoires publics ou privés. 


\section{Combined XRF, XRD, SEM-EDS and Raman analyses on}

serpentinized harzburgite (Nickel laterite mine, New Caledonia): implications for exploration and geometallurgy

Yassine El Mendili ${ }^{\dagger \neq}$, Daniel Chateignert, Beate Orberger ${ }^{\dagger}$, Stéphanie Gascoint $^{\dagger}$, Jean-François Bardeauß, Sébastien Petit' , Cédric Duée" , Monique Le Guen ${ }^{\perp}$, and Henry Pilliere ${ }^{\#}$

${ }^{\dagger}$ CRISMAT-ENSICAEN, UMR CNRS 6508, Normandie Université, 6 boulevard Maréchal Juin, 14050 Caen, France

‡ ESITC, École Supérieure d'Ingénieurs des Travaux de la Construction, COMUE-Normandie-Université, Caen, France.

§ GEOPS, Université Paris-Sud, UMR 8148 (CNRS-UPS), Bât. 504, 91405 Orsay, France

§IMMM, Le Mans Université, UMR6283 CNRS, Avenue Olivier Messiaen, 72085 Le Mans, France

"BRGM, 3 Avenue Claude Guillemin, BP 36009, 45060 Orléans Cedex, France

${ }^{\perp}$ ERAMET Nickel, Division Mines et Métaux, 1 Avenue Albert Einstein, 78190 Trappes, France

\# Thermo Fisher Scientific, 405, Chemin Départemental, 45410 Artenay

Supplementary information

Quantitative phase analysis by XRD 
Olivine group: forsterite. The Rietveld refinement was not possible with the pure forsterite or Fe-Mg olivine but with the Ni substitution in forsterite.

The average nickel content in forsterite in our study is about 3000 ppm.

Results from a representative structure refinement of forsterite are shown in Table S1.

Table S1. Refined atomic parameters for forsterite

\begin{tabular}{|c|c|c|c|c|}
\hline Atom & $\begin{array}{c}\text { Wyckoff } \\
\text { position }\end{array}$ & $x / a$ & $y / b$ & $z / c$ \\
\hline $\mathrm{Mg1} 1 \mathrm{Ni}$ & $4 a$ & 0 & 0 & 0 \\
\hline $\mathrm{Mg2-Ni}$ & $4 c$ & 0.991 & 0.277 & 0.250 \\
\hline $\mathrm{Si}$ & $4 c$ & 0.426 & 0.094 & 0.250 \\
\hline $\mathrm{O} 1$ & $4 c$ & 0.765 & 0.091 & 0.250 \\
\hline $\mathrm{O} 2$ & $4 c$ & 0.221 & 0.447 & 0.250 \\
\hline O3 & $4 d$ & 0.277 & 0.163 & 0.033 \\
\hline
\end{tabular}

The refined unit-cell parameters of Ni-forsterite are $a=4.74 \pm 0,01 \AA, b=$ $10.19 \pm 0,01 \AA$ and $c=5.93 \pm 0,02 \AA$, while those expected for pure forsterite are $a=4.75, b=10.20$ and $c=5.98 \AA^{78}$, proving the decrease of cell parameters. Since the $\vec{c}$ axis is parallel to the edge-sharing M1-M1-M1 spine of the zigzag octahedral chain, a change in the M1 octahedron size has a 
significant influence on the $\vec{c}$ axis $^{2}$. The shrinkage of $a$ is smaller because every second octahedral chain in this direction is unoccupied ${ }^{79}$.

Table 2 indicates a strong preference of $\mathrm{Ni}^{2+}$ for the $\mathrm{M} 1$ site. Indeed, the occupancies are (in \%): $98.1 \mathrm{Mg}+1.9 \mathrm{Ni}$ in the $\mathrm{M} 1$ sites and $99.7 \mathrm{Mg}+0.3 \mathrm{Ni}$ in the M2 sites. The M2 sites are larger than the M1 sites in forsterite. This implies that the larger cations $\mathrm{Mg}$ over $\mathrm{Ni}$ tend to occupy the larger M2 sites in olivine.

Pyroxene group: enstatite. The detected pyroxene in our XRD pattern is the ortho-enstatite with $11.6 \pm 0.5 \%$ of the total weight. Rietveld refinement analysis was performed then with orthorhombic enstatite based on the space group Pbca for texture correction.

The refined unit cell parameters are $a=18.318, b=8.853$ and $c=5.179 \AA$ with a crystallite size of $914 \mathrm{~nm}$. The cell parameters values correspond to those reported in literature ${ }^{80}$, for $\mathrm{Ni}$-free enstatite.

\section{Clay minerals: talc and sepiolite.}


We encountered some problems to refine the talc phase and especially due to the shift of the peaks towards low angles compared to the expected values for Ni-free phase. This shift is due to the Ni substitution in Mg-talc ${ }^{81}$.

Rietveld refinement was possible with Ni-talc within the monoclinic space group C12/c1 using a simple isotropic crystallite size and microstrain linebroadening model.

The refined unit cell parameters are $a=5.421, b=9.158, c=18.283 \AA$ and $\beta=108.61^{\circ}$, with a crystallite size of $104 \mathrm{~nm}$. The cell parameter values are smaller than those reported in the literature ${ }^{82}$. This suggests $\mathrm{Ni}$ incorporation in the talc structure. Indeed, as for forsterite, $\mathrm{Ni}$ substitution in the talc structure will induce a small decrease in the cell parameters compared to those of Ni-free talc.

For this phase, also (Table 2), a strong preference of $\mathrm{Ni}^{2+}$ for the $\mathrm{M} 1$ site is observed. Indeed, the occupancies are (in $\%): 78.1 \mathrm{Mg}+21.9 \mathrm{Ni}$ in the $\mathrm{M} 1$ sites and $96.4 \mathrm{Mg}+3.6 \mathrm{Ni}$ in the $\mathrm{M} 2$ sites, signing a much larger $\mathrm{Ni}$ incorporation in this phase, however less present in the sample. 
Sepiolite $\mathrm{Mg}_{4} \mathrm{Si}_{6} \mathrm{O}_{15}(\mathrm{OH})_{2} \cdot 6 \mathrm{H}_{2} \mathrm{O}$, a soft white clay mineral, is detected in our XRD pattern with a weight fraction of 5.6 vol.\%. For the refinement, we used the Ni-free sepiolite model proposed by Post et al., ${ }^{83}$. Within this model, sepiolite is orthorhombic, with the space group Pncn and approximate cell parameters $a=13.422, b=2 a, c=5.230 \AA$ with a crystallite size of $115 \mathrm{~nm}$. In the refinement, the occupation number of the different atomic positions corresponds to those given by Brauner and Preisinger ${ }^{84}$, three hydrous species: $\mathrm{OH}$ anions in the $\mathrm{O} 2$ site, coordinated to $\mathrm{Mg} 1, \mathrm{Mg} 2$, and $\mathrm{Mg}$; structural $\mathrm{H}_{2} \mathrm{O}$ at the $\mathrm{O} 10$ site, where it completes the $\mathrm{Mg} 4$ coordination at the edges of the Mg- $\left(\mathrm{O}, \mathrm{OH}, \mathrm{H}_{2} \mathrm{O}\right)$ octahedral strips; and three zeolitic $\mathrm{H}_{2} \mathrm{O}$ positions in the tunnels.

Quartz and periclase. $\alpha$-quartz and periclase were also detected and refined. The presence of quartz $\left(\mathrm{SiO}_{2}\right)$ is related to serpentinization producing high amounts of silica in aqueous solutions. The quartz model (trigonal space group $\mathrm{P}_{2} 21$ ) optimized in our study resulted in lattice parameters of $\mathrm{a}=4.920$ $\AA ̊$ and $c=5.042 \AA$ with a crystallite size of $250 \mathrm{~nm}$. These latter are usual for quartz ${ }^{85,86}$, observed here at $2.4 \%$. For the refinement of periclase phase 
(MgO, cubic, $F m-3 m$ ), a lattice parameter $a=4.209 \AA$ is refined with a crystallite size of $132 \mathrm{~nm}$. Periclase and quartz represent a sum of $6.2 \%$ of the total volume.

\section{Raman experiments}

Serpentine group: lizardite. The modes at 130, 201, 231, 348, 388, 620, and $692 \mathrm{~cm}^{-1}$ are characteristics of lizardite serpentine. The strong band at 231 $\mathrm{cm}^{-1}$ is attributed to $\mathrm{O}-\mathrm{H}-\mathrm{O}$ vibrations, where $\mathrm{O}$ is the non-bridging oxygen of a $\mathrm{SiO}_{4}$ tetrahedron and $\mathrm{H}$ is the hydrogen of the outer $\mathrm{OH}$ group of the adjacent layer ${ }^{10}$. The band at $130 \mathrm{~cm}^{-1}$ is attributed to the Si-Ob-Si bending mode ${ }^{33}$. The weak bands at 201 and $348 \mathrm{~cm}^{-1}$ are assigned to the $A_{1 \mathrm{~g}}$ mode of $\mathrm{Mg}(\mathrm{O}, \mathrm{OH})_{6}$ group and to the $\mathrm{SiO}_{4}$ bending mode, respectively ${ }^{32}$. The large band at $462 \mathrm{~cm}^{-1}$ is associated to the deformation of the $\mathrm{SiO}_{4}-\mathrm{MgO}_{4}$ tetrahedra ${ }^{11}$. The intense band at $691 \mathrm{~cm}^{-1}$ is attributed to the symmetric stretching mode $\left(v_{s}\right)$ of the $\mathrm{Si}-\mathrm{Ob}-\mathrm{Si}$ groups ${ }^{11}$. The band at 388 is observed in the spectra and assigned to the $\mathrm{v}_{5}(\mathrm{e})$ bending modes of the $\mathrm{SiO}_{4}$ tetrahedra ${ }^{30,31}$. The band at $620 \mathrm{~cm}^{-1}$ is assigned to $\mathrm{OH}-\mathrm{Mg}-\mathrm{OH}$ translation modes. 
Olivine group: forsterite. Olivine has 81 optical modes but only 36 of which are Raman active $\left(11 A_{g}+11 B_{1 g}+7 B_{2 g}+7 B_{3 g}\right)^{35,36}$. For forsterite, the Raman spectrum (Figure 6b) can be divided into 3 regions: $<400 \mathrm{~cm}^{-1}, 400-800 \mathrm{~cm}^{-1}$ and $800-1100 \mathrm{~cm}^{-1}$. Bands between 800 and $1000 \mathrm{~cm}^{-1}$ can be classified as internal stretching vibrational mode of $\mathrm{SiO}_{4}$ tetrahedra. The dominant feature in this region is a doublet with peaks at 821 and $852 \mathrm{~cm}^{-1}$. These peaks result from coupled $v_{1}$ symmetric and $v_{3}$ asymmetric vibrations of $\mathrm{SiO}_{4}$ tetrahedra ${ }^{35,40}$. Bands in the $400-800 \mathrm{~cm}^{-1}$ region are mainly from $\mathrm{SiO}_{4}$ internal bending vibrational modes, while those below $400 \mathrm{~cm}^{-1}$ are dominated by the rotation and translation of the tetrahedra $\left(\mathrm{SiO}_{4}\right)^{4-}$ as well as magnesium motion $^{35}$.

\subsection{Raman experiments.}

Pyroxene group: enstatite. Raman vibrational modes were observed for enstatite in the wavenumber range between 100 and $1200 \mathrm{~cm}^{-1}$. Raman spectrum of enstatite (Figure 6c) is characterized by (1) the stretching Si-O non-bridging and bridging modes at $1015 \pm 20 \mathrm{~cm}^{-1}$ and $870 \pm 50 \mathrm{~cm}^{-1}$, 
respectively; (2) the symmetric Si-O-Si bending modes at $670 \pm 20 \mathrm{~cm}^{-1}$ and (3) metal-oxygen bending and stretching modes below $600 \mathrm{~cm}^{-1} .41,87$

Reynard et al., ${ }^{78}$ reported a quick way to identify enstatite polymorphs using Raman spectra. There is a cell doubling in going from protoenstatite to orthoenstatite and correspondingly more peaks are observed in the Raman spectra of orthoenstatite compared to protoenstatite. Indeed, a single peak around $675 \mathrm{~cm}^{-1}$ can be used as diagnostic feature for protoenstatite, whereas orthoenstatite exhibits a doublet in the same frequency region (665 and $\left.690 \mathrm{~cm}^{-1}\right)$. Therefore, the lower spectrum can be assigned as orthoenstatite. This finding is in agreement with stability field of orthoenstatite in peridotite rocks, while the clino to protoenstatite transformation occurs at temperature at about $1250^{\circ} \mathrm{C}^{88}$.

Clay minerals: talc.

The spectrum has two strong Raman bands around $193 \mathrm{~cm}^{-1}$ and $674 \mathrm{~cm}^{-1}$. The later band is attributed to symmetrical stretching vibrations of the SilO(bridging)।Si bond in $\mathrm{SiO}_{4}$ tetrahedra, while the former at $193 \mathrm{~cm}^{-1}$ can be attributed to the stretching vibration of $\mathrm{MO}_{6}$ octahedra (where $\mathrm{M}$ is $\mathrm{Mg}$ and/or 
$\mathrm{Ni}$ ) of a talc-type structure ${ }^{44,45}$. The weak Raman bands at 1053 and $1023 \mathrm{~cm}^{-}$

1 are assigned to $\mathrm{v}_{4}(\mathrm{e})$ and $\mathrm{v}_{2}(\mathrm{e})$ non-bridging Si-O stretching modes, respectively. Raman spectrum shows the expected $v_{6}(e)$ and $v_{3}(e)$ modes of $\mathrm{SiO}_{4}$ at $458 \mathrm{~cm}^{-1}$ and $410 \mathrm{~cm}^{-1}$, respectively. In addition, a relatively intense band at $364 \mathrm{~cm}^{-1}$ attributed to $\mathrm{v}_{5}(\mathrm{e})$ modes of $\mathrm{SiO}_{4}$ are present in the spectrum. For Mg-talc, the stretching vibration of $\mathrm{MO}_{6}$ octahedron band of talc is expected at $196 \mathrm{~cm}^{-1}$.

Table S2. Raman vibration modes of lizardite, forsterite, orthoenstatite and Ni-talk. The symmetries and assignments are based on those reported in literature

\begin{tabular}{|c|c|}
\hline Symmetries and assignments & $\begin{array}{c}\text { Raman shift (cm- } \\
\left.{ }^{1}\right)\end{array}$ \\
\hline Lizardite $^{30-33}$ & \\
\hline Si-Ob-Si bending mode & 130 \\
\hline $\mathrm{A}_{1 \mathrm{~g}}$ mode of $\mathrm{Mg}(\mathrm{O}, \mathrm{OH})_{6}$ group & 201 \\
\hline $\mathrm{O}-\mathrm{H}-\mathrm{O}$ vibrations & 231 \\
\hline $\mathrm{A}_{1 \mathrm{~g}}$ mode of $\mathrm{Mg}(\mathrm{O}, \mathrm{OH})_{6}$ group & 348 \\
\hline $\mathrm{v}_{5}(\mathrm{e})$ bending modes of the $\mathrm{SiO}_{4}$ tetrahedra & 388 \\
\hline $\mathrm{SiO}_{4}-\mathrm{MgO}_{4}$ tetrahedra & 462 \\
\hline $\mathrm{OH}-\mathrm{Mg}-\mathrm{OH}$ translation modes & 620 \\
\hline$\left(v_{s}\right)$ of the Si-Ob-Si groups & 691 \\
\hline
\end{tabular}




\begin{tabular}{|c|c|}
\hline Forsterite $35,36,40$ & \\
\hline Internal stretching vibrational mode of $\mathrm{SiO}_{4}$ tetrahedra & $<400$ \\
\hline $\mathrm{SiO}_{4}$ internal bending vibrational modes & $400-800$ \\
\hline $\begin{array}{c}\text { Rotation and translation of }\left(\mathrm{SiO}_{4}\right)^{4-} \text { and magnesium } \\
\text { motion }\end{array}$ & $800-1100$ \\
\hline Orthoenstatite ${ }^{41,87,88}$ & \\
\hline Metal-oxygen bending and stretching modes & $<600$ \\
\hline Symmetric Si-O-Si bending modes & 670 \\
\hline Si-Ob-Si bending mode & 870 \\
\hline Si-O non-bridging mode & 1015 \\
\hline Ni-Talc 44,45 & \\
\hline Stretching vibration of $\mathrm{MO}_{6}$ octahedra & 193 \\
\hline $\mathrm{MO}_{6}$ octahedron band & 196 \\
\hline $\mathrm{v}_{5}(\mathrm{e})$ non-bridging $\mathrm{Si}-\mathrm{O}$ stretching modes & 364 \\
\hline $\mathrm{v}_{3}(\mathrm{e})$ non-bridging $\mathrm{Si}-\mathrm{O}$ stretching modes & 410 \\
\hline $\mathrm{v}_{6}(\mathrm{e})$ non-bridging Si-O stretching modes & 458 \\
\hline SilO(bridging) \Si bond & 674 \\
\hline $\mathrm{v}_{4}(\mathrm{e})$ non-bridging $\mathrm{Si}-\mathrm{O}$ stretching modes & 1053 \\
\hline $\mathrm{v}_{2}(\mathrm{e})$ non-bridging $\mathrm{Si}-\mathrm{O}$ stretching modes & 1023 \\
\hline
\end{tabular}

\section{REFERENCES}

(78) Smyth, J. R.; Hazen, R. M. The crystal structures of forsterite and hortonolite at several temperatures up to 900 C. Am. Mineral, 1973. 58, 588- 
(79) Boström, D. Single-crystal X-ray diffraction studies of synthetic Ni-Mg olivine solid solutions. Am. Mineral. 1987. 72, 965-972.

(80) Periotto, B.; Balic-Zunic, T.; Nestola, F.; Katerinopoulou, A.; Angel, R. J. Re-investigation of the crystal structure of enstatite under high-pressure conditions. Am. Mineral. 2012, 97, 1741-1748.

(81) Dumas, A.; Mizrahi, M.; Martin, F.; Requejo, F. G. Local and ExtendedOrder Evolution of Synthetic Talc during Hydrothermal Synthesis: Extended X-ray Absorption Fine Structure, X-ray Diffraction, and Fourier Transform Infrared Spectroscopy Studies. Cryst. Growth. Des. 2015, 15, 5451-5463.

(82) Gruner, J. W. The crystal structures of talc and pyrophyllite. Zeitschrift fuer Kristallographie, Kristallgeometrie, Kristallphysik, Kristallchemie (144, 1977), 1934, 88, 412-419.

(83) Post, J. E.; Bish, D. L.; Heaney, P. J. Synchrotron powder X-ray diffraction study of the structure and dehydrationbehavior of sepiolite. Am. Mineral. 2007, 92, 91-97. 
(84) Brauner, K.; Preisinger, A. Struktur und entstehung des sepioliths. Tschermaks Mineralogische und Petrographische Mitteilungen, 1956, 6, 120140.

(85) Le Page, Y.; Donnay, G. Refinement of the crystal structure of lowquartz. Acta Crystallogr, Sect. B: Struct. Crystallogr. Cryst. Chem. 1976, B32, 2456-2459.

(86) Cohen, A. J.; Summer, G. G. Relationships among impurity contents, colour centers and lattice constants in quartz. Amer. Mineral. 1958, 43, 58-68.

(87) Reynard, B.; Bass, J. D.; Jackson, J. M. Rapid identification of steatiteenstatite polymorphs at various temperatures.J. Europ. Ceram. Soc. 2008, 28, 2459-2462.

(88) Heimann, R. B. Classic and Advanced Ceramics: From Fundamentals to Applications. Wiley-VCH Verlag GmbH \& Co. KGaA, Weinheim, 2010. 